\title{
TRICHOMONAS TENAX EMPYEMA IN AN IMMUNOCOMPROMISED PATIENT WITH ADVANCED CANCER
}

\author{
SHIOTA T.*, ARIZONO N.*, MORIMOTO T.**, SHIMATSU A.** \& NAKAO K.**
}

Summary :

A 53-year-old male acromegalic patient with advanced rectal adenocarcinoma developed pleuritis in the course of cobalt irradiation, steroid treatment and chemotherapy. Examination of drained pleural fluid demonstrated numerous motile organisms, which were identified as Trichomonas tenax by Giemsa staining. Peptostreptococcus micros was also detected in the cultures of pleural fluid and blood. Treatment with metronidazole successfully eliminated the protozoa and cured the pyothorax

KEY WORDS : Trichomonas tenax, empyema, pleural fluid, Peptosireptococcus micros, adenocarcinoma

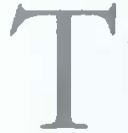
hree species of trichomonad parasitize human: Trichomonas vaginalis Donne, 1836, Pentatrichomonas bominis (Davaine, 1860) Wenrich, 1931, and Trichomonas tenax (Muller, 1773) Dobell, 1939. Trichomonas vaginalis usually inhabits the genital systems and P. bominis is found in the intestine. On the other hand, T. tenax is a generally harmless commensal organism in the human mouth, which is associated with poor dentition and oral hygiene. Several cases of pleural empyema caused by $T$. tenax have been reported (Memik, 1968; Walzer et al., 1978; Miller et al., 1982; Hersh, 1985; Ohkura et al., 1985). We report the first co-infected case of empyema with T. tenax and Peptostreptococcus micros.

\section{CASE REPORT}

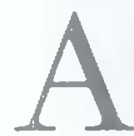

53-year-old male acromegalic patient with rectal adenocarcinoma metastasizing in the brain, bone marrow and liver, was admitted to Kyoto University Hospital in Kyoto, Japan for cancer

\footnotetext{
" Department of Medical Zoology, Kyoto Prefectural University of Medicine, Kawaramachi Hirokoji, Kamigyoku, Kyoto 602, Japan. * Department of Medicine and Clinical Science, Kyoto University Graduate School of Medicine, 54 Shogoin Kawara-cho, Sakyoku, Kyoto 606, Japan.

Correspondence: Dr. Tsunezo Shiota

Tel: 0752515325 - Fax: 0752515328.

E-mail: shiotats@basic.kpu-m.ac.jp
}

Résumé : EMPYÈME À TRYCHOMONAS TZNAX CHEZ UN PATIENT IMMUNODÉPRIMÉ SOUFFRANT D'UN CANCER AVANCÉ

Un patient acromégalique ágé de 53 ans et souffrant d'un adénocarcinome rectal avancé a developpé une pleurésie au cours d'une irradiation au cobalt, d'un traitement aux stéroides et d'une chimiothérapie. L'examen du liquide pleural drainé a décelé de nombreux organismes mobiles qui furent identifiés en tant que Trichomonas tenax par une coloration de Giemsa. Des Peplostreptococcus micros furent aussi défectés dans les cultures du liquide pleural et le sang. Un rraitement avec du métronidazole a permis d'éliminer avec succès les protozoaires et de guérir la pleurésie purulente.

MOTS CLÉS : Trichomonas tenax, empyème, liquide pleural, Peptostreplococcus micros, adénocarcinome.

treatment. Irradiation of cobalt 60 was applied to the brain and bone marrow lesions. The patient was also given chemotherapy with methotrexate, fluorouracil and cis-Dichlorodiammine platinum for 5 cycles. The patient was treated with glycerol and dexamethasone for brain oedema. He had poor oral hygiene and pyorrhea alveolaris.

Laboratory findings at the end of chemotherapy were as follows: hemoglobin, $94 \mathrm{~g} / \mathrm{L}$; hematocrit, $28.3 \%$; red blood cells, $2890 \times 10^{9} / \mathrm{L}$; white blood cells, $17.1 \times$ $10^{9} / \mathrm{L}$; platelets, $133 \times 10^{9} / \mathrm{L}$; total protein, $5.4 \mathrm{mg} / \mathrm{dL}$; total bilirubin, $0.9 \mathrm{mg} / \mathrm{dL}$; GOT, $135 \mathrm{IU} / \mathrm{L}$; GPT, $159 \mathrm{IU} / \mathrm{L}$; alkaline phosphatase, $1132 \mathrm{IU} / \mathrm{L}$; LDH, $328 \mathrm{IU} / \mathrm{L}$; C-reactive protein, $22.1 \mathrm{mg} / \mathrm{dL}$; carcinoembryonic antigen, $864 \mathrm{ng} / \mathrm{mL}$; CA 19-9, $16444 \mathrm{U} / \mathrm{mL}$ and CA $125,165 \mathrm{U} / \mathrm{mL}$.

He suffered from pyothorax at the end of chemotherapy. On thoracentesis from the right pleural cavity, $200 \mathrm{~mL}$ of yellow, cloudy fluid was withdrawn and showed a large number of neutrophils and monocytes. Fresh wet preparations of the fluid revealed numerous flagellated, actively motile organisms with the typical appearance of trichomonads. The wet smears of trichomonads were immediately fixed in ethanol and stained with Giemsa. Cultures of pleural fluid and venous blood also yielded $P$. micros.

Metronidazole $(1000 \mathrm{mg}$ ) was given orally twice a day for five days. Trichomonads were positive in the drained fluid over two days and became negative 
from day three of the institution of metronidazole therapy. $P$. micros also disappeared after administration of ceftazidime, $2 \mathrm{~g} \times 11$ days and clindamycin, $900 \mathrm{mg}$ $\times 10$ days. Repeated examinations of mouth washings, gingival swabs, urine sediments and stools failed to reveal the presence of trichomonads before and after the administration of metronidazole.

\section{OBSERVATION OF TRICHOMONADS}

With direct light microscopic examination of pleural fluids, the organisms were readily identified as Trichomonas by the typical pear-shaped forms, flagellae, and undulating membranes. The characteristic wobbly, rolling motion was apparent.

The Giemsa-stained trichomonads (Fig. 1, left) had a length of 5 to $12 \mu \mathrm{m}$ (average $8.1 \mu \mathrm{m}$ ) and a width of 4 to $10 \mu \mathrm{m}$ (average $6.6 \mu \mathrm{m})(\mathrm{n}=50)$. They had four free flagellae 10 to $12.5 \mu \mathrm{m}$ in length (average $11.6 \mu \mathrm{m}$; $\mathrm{n}=36$ ) and a fifth on the margin of the undulating membrane which did not reach the posterior end of the body. The nuclei were generally ellipsoid or ovoid with its longer axis at a slight angle to the anteriorposterior axis of the organism. The cytoplasm was delicately granular. These morphological characteristics were consistent with the previous descriptions of T. tenax (Honigberg \& Lee, 1959; Beaver et al., 1984). Aggregates of different sizes of trichomonads were often seen (Fig. 1, right). The measurements of trichomonads also fell within the range reported for T. tenax ( Honigberg et al., 1959; Beaver et al., 1984), while those of $T$. vaginalis, from similarly fixed and stained preparations obtained from a vaginitis patient, averaged $13.8 \mu \mathrm{m}(9-19 \mu \mathrm{m})$ in length and $8.1 \mu \mathrm{m}(5$ $13 \mu \mathrm{m})$ in width $(\mathrm{n}=50)$.

\section{DISCUSSION}

7 richomonas tenax is an organism of the human mouth, inhabiting the tartar around the teeth, in cavities of carious teeth and in pus pockets in tonsillar follicles. Transmission is direct, from droplet spray from the mouth, kissing, or use of contaminated dishes and drinking water. Over 160 cases of trichomonad infection in upper respiratory tracts were reported throughout the world from 1867 to 1987 (Honigberg, 1990). A systematic survey using bronchoscopy and culture methods showed that T. tenax was found in the bronchi in 37 out of 370 cases $(10 \%)$, mainly in patients with chronic pneumonia and chronic bronchitis in the USSR (Kazakova et al., 1980). In contrast, trichomonad infection in the pleural cavity is relatively rare. Five cases of pleuropulmonary infections have been reported from the USA (Memik, 1968; Walzer et al., 1978; Miller, 1982; Osborne et al., 1984; Hersh, 1985), two from France (Abed et al., 1966; Houin et al., 1973) and one from Japan (Ohkura et al., 1985). Furthermore, four cases showed co-infection of T. tenax and anaerobic bacteria (Memik, 1968; Walzer et al., 1978; Miller et al., 1982; Ohkura et al., 1985).

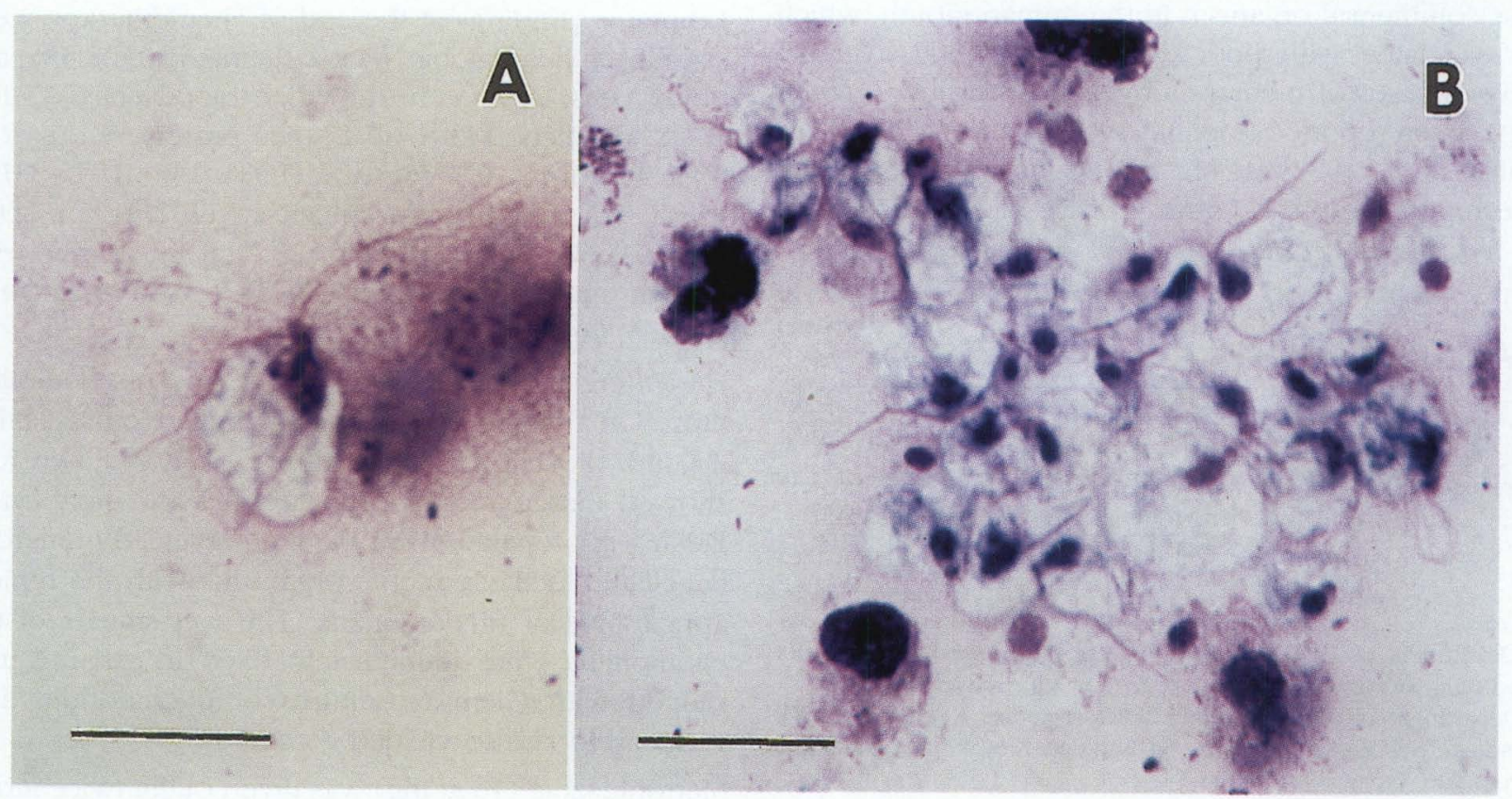

Fig. 1. - Trichomonas tenax in the pleural fluid showing a typical shape (A) and an aggregate of different sizes of trichomonads (B). Giemsa stain. Scale bar $=10 \mu \mathrm{m}$. 
In Japan, Ohkura and colleagues (1985) reported mixed infection with T. tenax and Escherichia coli in the purulent pleural effusion from a 70 -year-old homosexual man. In the present case, P. micros was also identified in pleural effusion. Since T. tenax is reported to feed on microorganisms in its environment (Honigberg et al., 1957), it is suggested that trichomonads could easily proliferate in the presence of concomitant bacterial infection.

The source of trichomonads in the present case was most likely the mouth, a known habitat of $T$. tenax species, because the patient had pyorrhea alveolaris. Searches for trichomonads in oropharyngeal washings and sputum, however, gave negative results. Walzer and colleagues (1978) and Miller and colleagues (1982) reported cases with trichomonas pleural empyema, but were unable to find the organism outside the pleural space. They suggested that oropharyngeal trichomonads were too few in number to be found in oral washing. Trichomonas tenax is widely distributed in the work and is generally found in the human mouth. Physicians caring for immunocompromised patients should include $T$. tenax empyema in the differential diagnosis of empyema of unknown origin. Wet preparation and Giemsa staining are essential for confirming the diagnosis. The importance of making the diagnosis is underscored by the availability of effective treatment with metronidazole.

\section{REFERENCES}

Abed L., Dellemotte J., Marill R., Ripert C. \& Tordjman G. Localisation pleuro-pulmonaire du Trichomonas. Bulletin de la Société de Patbologie Exotique, 1966, 59, 962-964.

Beaver P.C., Jung R.C. \& Cupp E.W. Trichomonas tenax, in: Clinical parasitology. 9th ed. Philadelphia, Lea \& Febiger, 1984, 47-48.

DolsELL C. The common flagellate of the human mouth, Trichomonas tenax (OFM): Its discovery and its nomenclature. Parasitology, 1939, 31, 138-146.

Donne A. Animalcules observés dans les matières purulentes et le produit des sécrétions des organes génitaux de lhomme et la femme. Comptes Rendus Hebdomadaires des Séances de l'Academie des Sciences Paris, 1836, 3, 385-386.

Hersh S.M. Pulmonary trichomoniasis and Trichomonas tenax. Joumal of Medical Microbiology, 1985, 20, 1-10.

Honigberg B.M., Mandel M., Lee J.J. \& Braunthal S.D. Cultivation of Trichomonas tenax with a single type of bacteria. Journal of Protozoology, 1957, 4 (suppl) ), 5.

Honigiberg 13. M. \& Lle J.J. Structure and division of Trichomonas tenax (O.F. Müller). American Journal of Hygiene, $1959,69,177-201$

Honigberg B.M. Trichomonads found outside the urogenital tract of humans. In: Trichomonads Parasitic in Humans. Honigberg B.M. (ed), Springer-Verlag, New York, 1990, 342-366.
Holin R., Denlau M., Romano P. \& Poirot J.L. Trichomonase pleurale. Bulletin de la Société de Patbologie Exotique, 1973, 66, 627-631.

Kazakova I., Teras J., Roigas E., Sardis H., Kumm R. \& Kaal V. Trichomonad invasion in respiratory tract and specific agglutinins in the blood sera of patients suffering from lung diseases. Izvestiia Akademii nauk Estonskoi SSR. Biologiia, $1980,2,85-94$.

MFмiK F. Trichomonads in pleural effusion. Joumal of the American Medical Association, 1968, 204, 1145-1146.

Miller M.J., Leith D.E., Brooks J. R. \& Fencl V. Trichomonas empyema. Thorax, 1982, 37, 384-385.

Ohkura T., Suzuki N. \& Hashiguchi Y. Occurrence of Trichomonas tenax in pleural effusion: A case report and a brief review of literatures. Japanese Journal of Tropical Medicine and Hygiene, 1985, 13, 295-299.

Osiborne P.T., Giltman L.I. \& Uthman E.O. Trichomonads in the respiratory tract: A case report and literature review. Acta Cytologica, 1984, 28, 136-138.

WALZER P.1)., RUTHERFORD I. \& EAST R. Empyema with Trichomonas species. American Review of Respiratory Disease, $1978,118,415-418$.

WeNrich D.H. Morphological studies on the trichomonad flagellates of man. Archivos de la Sociedad de Biologia de Montevideo, 1931, 5 (suppl.), 1185-1204.

Reçu le 27 avril 1998 Accepté le 27 juin 1998 